\title{
THE EQUIVALENCE OF ENGLISH MODAL AUXILIARIES INTO INDONESIAN
}

\author{
Rr.Astri Indriana Octavita \\ Pendidikan Bahasa Inggris \\ Fakultas Bahasa dan Seni Universitas Indraprasta PGRI \\ Jl. Nangka No.58 Tanjung Barat, Jakarta Selatan, Indonesia \\ indrianafadton@yahoo.com
}

\begin{abstract}
This study aims to find out the equivalence of English Modal Auxiliaries into Indonesian. The main question of the study is how the translator renders English modal auxiliaries into Indonesian. Since English modal auxiliaries are different from Indonesian modal auxiliaries, it may lead to the problems of rendering and understanding English modal auxiliaries for Indonesian novice translator. The Translator must be able to communicate these English modal auxiliaries into Indonesia in natural way or translation The method employed in this study is a qualitatitve descriptive method to describe and explain the equivalence English modal auxiliaries into Indonesian. Data Analysis is done through 3 steps based on Miles and Huberman's Interactive Model. After analyzing the data, it was found that English modal auxiliaries consisting of could, may, will, can, should, would, shall, must, might, and used to were translated into different words according to the contexts. In addition, modal auxiliaries are sometimes not translated depending on the context.
\end{abstract}

Key Words : English modal auxiliaries, translation, Indonesian

\section{KESETARAAN MODAL INGGRIS AUXILIARIES KE DALAM BAHASA INDONESIA}

\begin{abstract}
Abstrak
Penelitian ini bertujuan untuk mengetahui kesetaraan modal Inggris auxiliaries ke Indonesia. Pertanyaan utama penelitian ini adalah bagaimana penerjemah membuat modal Inggris auxiliaries ke dalam bahasa Indonesia. Modal Inggris auxiliaries berbeda dengan modal Indonesia auxiliaries, mungkin ini dapat menyebabkan masalah rendering dan memahami modal Inggris auxiliaries untuk penerjemah pemula di Indonesia. Penerjemah harus bisa mengkomunikasikan modal Inggris auxiliaries ini ke dalam bahasa Indonesia secara wajar atau terjemahan. Metode yang digunakan dalam penelitian ini adalah metode deskriptif kualitatif yaitu yang menggambarkan dan menjelaskan kesetaraan modal Inggris auxiliaries ke dalam bahasa Indonesia. Analisis data dilakukan melalui 3 langkah berdasarkan Miles dan Huberman Interaktif Model. Setelah menganalisis data, ditemukan bahwa modal Inggris auxiliaries yang terdiri dari bisa, mungkin, akan, dapat, harus, akan, akan, harus, mungkin, dan digunakan untuk diterjemahkan ke dalam kata-kata yang berbeda sesuai dengan konteks. Selain itu, modal auxiliaries terkadang tidak diterjemahkan, tergantung pada konteks yang ada.
\end{abstract}

Kata kunci : modal Inggris auxiliaries, terjemahan, bahasa Indonesia

\section{INTRODUCTION}

The growth of technology in this globalization era, English as an international language is used in most countries in the world, especially in Indonesia, which use it as a second language. People get information from others via language. It's not only orally but also in written way. We know a lot 
of information from books. As we know, many books exist in this world written in many languages, the language that is different in system from our own. It is definitely difficult for us to understand books and texts that are written in other languages other than our mother tongue. In this case, auxiliary plays a very essential role. Without auxiliary, people may not understand any information exist in magazines, books, newspaper, etc. It is clearly to say that not only will translation help human being understand other language but it also useful for human being to exchange information in order to pace out with the development.

As a form of communication, translation has the role to deliver a written message from Source Language (SL) into Target Language (TL). Carrying out this process is no easy task for a translator. The message must be convey in a way for a TL readers to receive the same impression obtained by original message of SL texts. If the message fails to be understood by TL readers then it may be assumed that the translation is unsuitable. What translation is all about is how the message uttered in SL texts into TL readers may meet the intention of the SL author. As to what Newrmark stated that translation is rendering the meaning of a text into another language in the way that the author intended the text (1988:5).

In its further development, translation is understood as to transfer the meaning of the source language into the receptor language. Under this principle, translation is then comprehended as the process of changing speech or writing from one language, the source language into another, the target language or the target language version that results from this process (Dictionary of Language Teaching and Applied Linguistics, 1993).
Translating is transferring the message from the source language to the target language. The transferring is done from the form of the source language to the form of the target language. It is the message should be transferred and defended. Translating a text from one language to another is a difficult task. The fact that some body is able to handle a foreign language fairly well does not necessarily qualify him / her as a translator producing a written text using another text as a basis is a much more complex phenomenon than what is commonly believed. The afore mentioned complexcity becomes even more evident when the text in question deals with specialized subjects and when the source language and the target language are not in the same language family, for example English and Indonesian.

We have varied cultures, customs, and language, including in this study English and Indonesia. Sometimes, we don't understand what the meaning of the language is. Culture plays the dominant part in the translation process. The translation must be accurate, natural, and clear and the translator must be aware of the contexts. The problem becomes one of translation since the cultures concerned were studied through their emergence in texts (oral tradition, narration of fishing expeditions, etc.) The contexts involve in translation mostly concerns with cultural differences which Malinowski refer to as context of situation and culture (Hatim \& Mason, 1990:37)

English and Indonesian have different background. They derived from different language group; English is Indo-European group while Indonesian language is derived from Austronesia. Differences of cultural values are also important factors in understanding a series of related terms (Nida, 
1001:37).The differences English and Indonesian language structure and cultures may be the most serious problem for translators. There are a lot of misinterpretations or even misunderstanding among readers as a consequence of wrong translation. So far, it has been found a translation pattern from English into Indonesia. So, a translator skill is required.

The translator's goal should be to reproduce in the receptor language a text which communicate the same message as the source language but using the natural grammatical and lexical choices of the receptor language (1984:17).

\section{DISCUSSION}

Translation has three crucial elements that must be exist to create communication they are: source, message, and receiver. The translator's task is to do a communication analysis before he/she translates. This analysis will not be sufficient without analyzing the role of the recipient in translation processs. It is important for a translator to know about the background of the language he / she used as SL or TL (religion, education) and the linguistic background (national language, mother language, dialect).

Translation has been described as an effort to transfer or to render meaning from one language into another language. Translation has been widely defined throughout many ways with different theoretical framework. Though it may not necessarily represent all the theories exist in the field of translation, this study includes several theories from experts in translation. Generally, all the theories emphasize that the main element in quest of equivalence is translator's knowledge regarding the norms of source language and target language. In translating one language into another, the transfer of meaning is far more crucial than the transfer of form or even word for word translation.

Translation is a craft consisting in the attempt to replace a written message and / or statement in one language by the same message and / or statement in another language.

Translation according to Larson consists of transferring the meaning of the source language into the receptor language. She further explains that the activity of transferring is done by going from the form of the first language to the form of second language by way of semantic structure. It is clearly stated that is the meaning which is being transferred and must be held constant and only the form changes from one form to another. The other form can be in the form of source language or target language. Larson also confirms her definition by explaining more that in order to achieve the best translation, a translation must be :

1. uses the normal language forms of the receptor language

2. communicate, as much as possible, to the receptor language speakers the same meaning that was understood by the speakers of the source language

3. Maintains the dynamics of the original source language.

Maintaining the 'dynamics' of the original source text means that the translation is presented in such a way that it will, hopefully, evoke the same response as the source text attempted to evoke.

Translation involves two different languages but each must possess the same message. This will evoke several problems on translation. According to Larson, translation is also a change of form (ibid:3). We are referring to the actual words, phrases, clauses, sentences, paragraphs, etc. Translation 
consists of transferring the meaning of the source language into the receptor language. Larson also stated that translation has been presented as a process, which begin with the source text, analyze this text into semantic SL

$$
\begin{aligned}
& \text { Text to be } \\
& \text { translated }
\end{aligned}
$$

Discover the Meaning structure, and then restructures this semantic structure into appropriate receptor language form in order to create an equivalent receptor language text, as in diagram:

TL

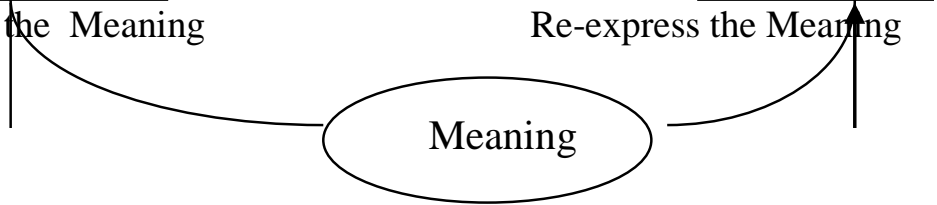

\section{Diagram 1}

A translator, no matter how competent he/she is, always realizes the difficulty to fulfill all the requirements mentioned in the previous paragraph. Is it possible to transfer the meaning of the source text into target text (Larson use the term receptor language). Wholly, no reduction no addition, as natural as possible into target language? It seems that such criteria are difficult to accomplish, as the quotes from some scholar:

"Traduttore, traditore" (an Italian saying, means: a translator is a traitor)

"Interpreting is not everybody's art" (Luther)

"Translations are like women-homely when they are faithful and unfaithful when they are lovely" (early Renaissance Italian writers) Catford (1965:20) defining translation as "the replacement of textual material in one language (source language) by an equivalent in another language (target language)." According to Newmark (1981:7) translation is a craft consisting in the attempt to replace a written message and/or statement in one language by the same message and/or statement in another language. The meaning of source language is the message that the source language expected to have an effect to the target language readers. The term message may be presented in the transfer of forms of one language into forms of other languages. Language cannot be separated from its cultural context (Simatupang, 1999/2000:8); it means that language may only be meaningful in the context of where that language is used in its own society. Therefore, translating is an act of cross-cultural and cross-language understanding in terms of linguistic and cultural.

According to definition of all the expert, the translation is not as simple as the people ascription. Translation is not simply process of seeking of equivalent of word from one Ianguage to other; dissimilar Ianguage in dictionary. In translation there are text, mean text, and process adjustment of result of translation in Ianguage of target so that fair looked to be without altering its contents. Result of translation even also have to can depict the unique of original text and [is] at one blow submitted/sent in the form of fair in target language.

Process is a series of actions or tasks performed in order to do make or achieve something (Oxford, 1996:922). 
Basically, the translator do activity when she / he translated some text. The process of translator is a steps which done by a translator before she/he do her/his
A. (Source Language )

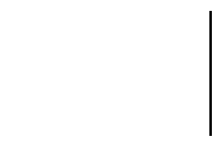

(Analysis )
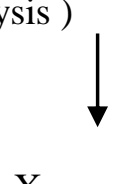

translation (Soemarno, $1998: 2$ ). Nida and Taber (1969: 33 ) made translation process in diagram 2

B. ( Target Language )

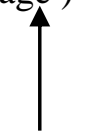

(restructuring)

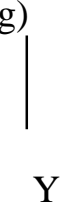

Diagram 2 : Translation Process by Nida

In the diagram, Nida and Taber separated process of translation with three steps, are analysis, transfer and restructuring. In Analysis translator analyze the text in language $\mathrm{A}$ from grammatical and words to find the meaning of text. The translator read all of source language text to know the content and meaning of that text. In transfer, the meaning of result from the analysis is change from language $\mathrm{A}$ to language B. Furthermore, in restructuring the translator adapted a message / meaning in language form in language B.Machali also contributes to the description of a process of translation (2000:38). Before a translator start to transfer meaning from SLT into TLT, he /she must perform a process of transference. In this phrase, a translator tires to ' replace ' the elements in SLT into the equivalent of TLT to avoid errors or inaccuracy in the process of transference, a translator can execute more than one analysis.

$$
\begin{aligned}
& \text { First Analysis } \longrightarrow \text { Transference } \longrightarrow \text { Second Analysis } \longrightarrow \text { First Correction of the } \\
& \text { transference } \longrightarrow \text { Third Analysis } \longrightarrow \text { Second Connection of the transference }
\end{aligned}
$$

Diagram 3 : Process Of Translation by Machali

After the first analysis of the SLT, the next phase is to transfer the SLT message into TLT. The translator must re-check again the result on his / her transference this is called second analysis. After the checking phase, the translator must make a correction of his / her transference, whether it meets the equivalent or not, or whether any inaccuracy present. This process may well be repeated several times as long as the translator feels the urgency to make further analysis.

\section{Auxiliary}

Auxiliary verbs is usually before another verb and help another verbs to form verb phrases (e.g. is leaving, would help). The category of verbs can therefore be divided into two sets, main or lexical verbs, and auxiliary verbs, which can co-occur in a verbal sequence only the highest verb in a verbal 
sequence is marked for tense and agreement regardless of whether it is a main or auxiliary verb. Some auxialiaries (be, do, and have) share with main verbs the property of having overt morphological marking for tense and agreement, while the modal auxiliaries do not. However, all auxiliary verbs differ from main verbs in several crucial ways. There are four kinds of auxiliary: auxiliary 'do, does, did ', auxiliary have, auxiliary be, and modal auxiliary.

\section{Modal Auxiliary}

Helping verbs or auxiliary verbs such as will, shall, may, might, can, could, must, ought to, should, would, used to, need are used in conjunction with main verbs to express shades of time and mood. There is also a separate section on the Modal Auxiliaries, which divides these verbs into their various meanings of necessity, advice, ability, expectation, permission, possibility, etc. and provides sample sentences in various tenses.

\section{RESEARCH METHOD}

\section{RESEARCH DESIGN}

This study employs a qualitative design. Bogdan and Taylor (in Moleong, 1995:3) define qualitative methodology is a research procedure which produces descriptive data of written and oral words from the subject or behavior observed. This approach is led to the background and the individuals themselves holistically. Therefore, this approach does not permit isolation of individual or organization into variable, but individual or organization must be included into one complete package.

The data gathered are in the form of words or verbal expressions. This merely because of qualitative method is employed. The report of the analysis is fiilled with quotations taken from the novels. To achieve the objectives of this study, the writer employs a descriptive analysis on the English modal auxiliaries into Indonesian. This kind of analysis is suitable to the aim of the study, which intends to give detailed description of why, what, and how something occurs. This analysis also used or to described the data as factual as possible. A descriptive analysis is employed in this study focuses on to the observation to the indication, events, and actual condition in present time (Soemanto, 1994:14). The descriptive analysis is employed in this study because it represent the actual condition which becomes the landmark of this study that is the translation of modal auxiliaries. The use of descriptive analysis is needed to explain or to describe such phenomenon as factual as possible.

There were ten kinds of modal auxiliaries found in the original novel, namely could, may, will, can, should, would, shall, must, might, and used to. Their translation varied according to the context. The rendering of could into Indonesian was dapat, maтpu, bisa, mungkin, and in same contexts could was not translated. This can be seen in the following diagram :

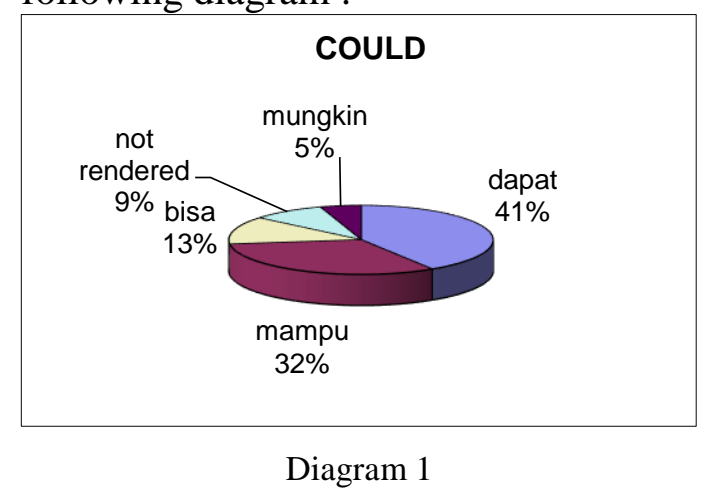

May was rendered into akan, boleh, bisa, mungkin, semoga, and in same contexts it was not rendered. This can be seen in the following diagram : 


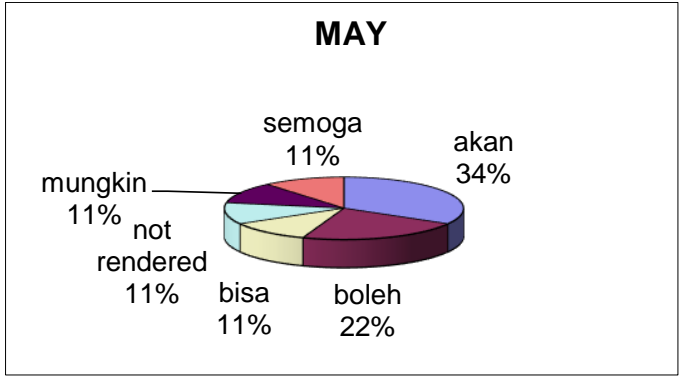

Diagram 2

Will was rendered into akan, dapat, bisa, and in same contexts it was not rendered. This can be seen in the following diagram :

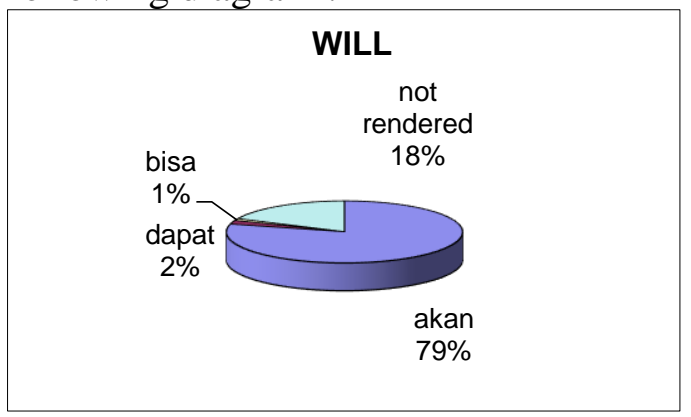

Diagram 3

Can was rendered into dapat, bisa, mungkin, mampu, and in same contexts it was not rendered. This can be seen in the following diagram :

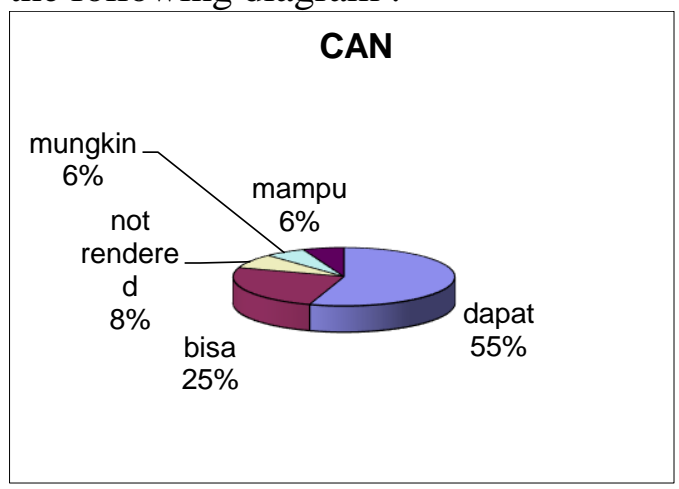

Diagram 4

Should was rendered into harus and in same contexts it was not rendered. This can be seen in the following diagram :

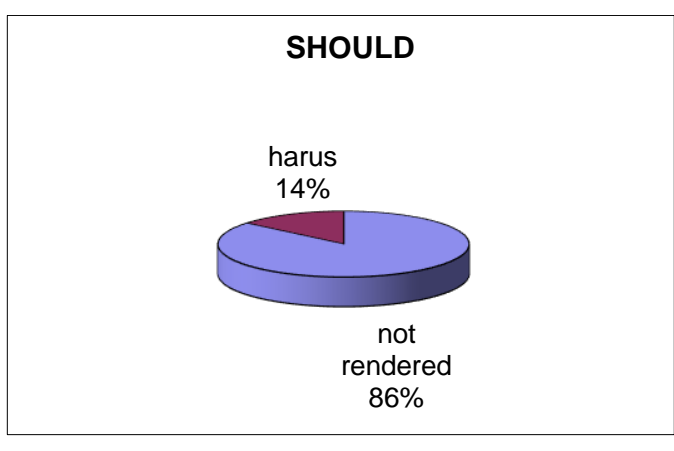

Diagram 5

Would was rendered into akan, and in same contexts it was not rendered. This can be seen in the following diagram :

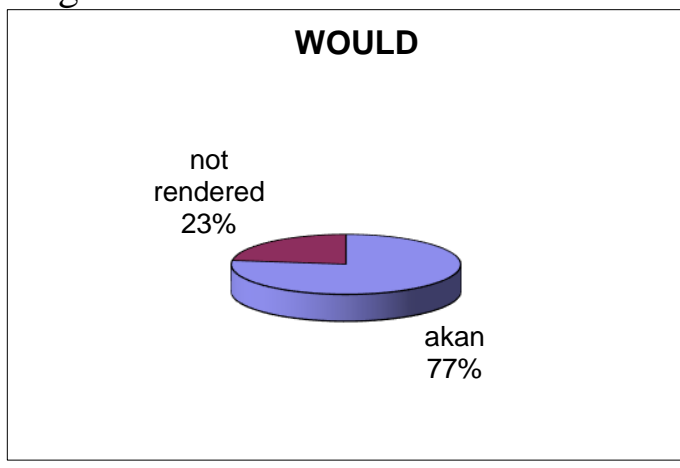

Diagram 6

Shall was rendered into akan, and in same contexts it was not rendered. This can be seen in the following diagram :

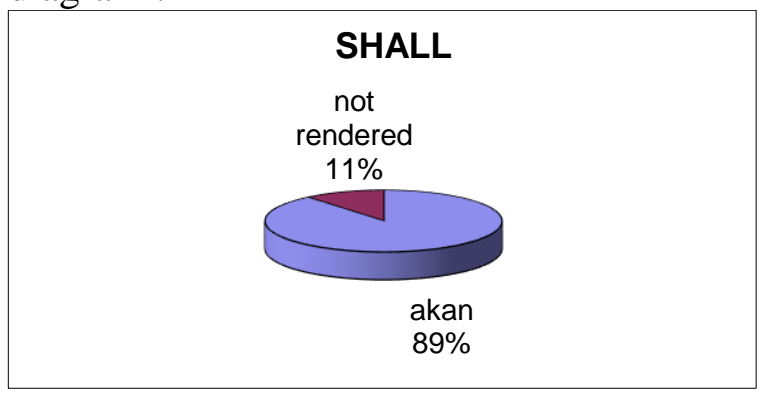

Diagram 7

Must in same contexts it was not rendered. This can be seen in the following diagram : 


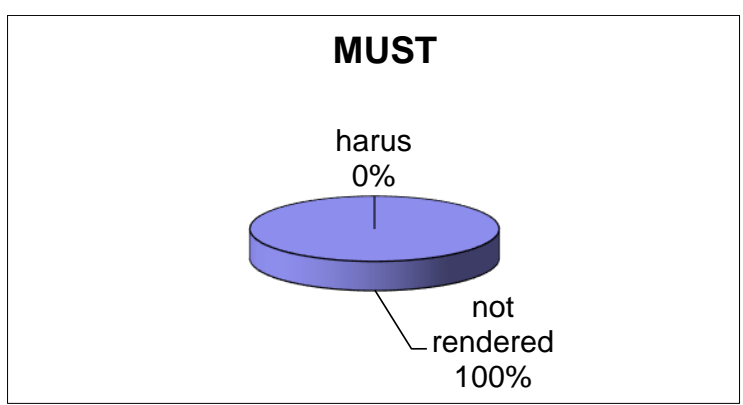

Diagram 8

Might was rendered into akan, and mungkin. This can be seen in the following diagram :

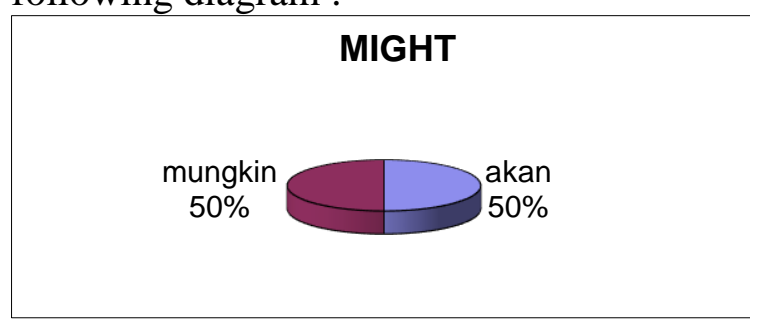

Diagram 9

Used to in same contexts it was not rendered. This can be seen in the following diagram :

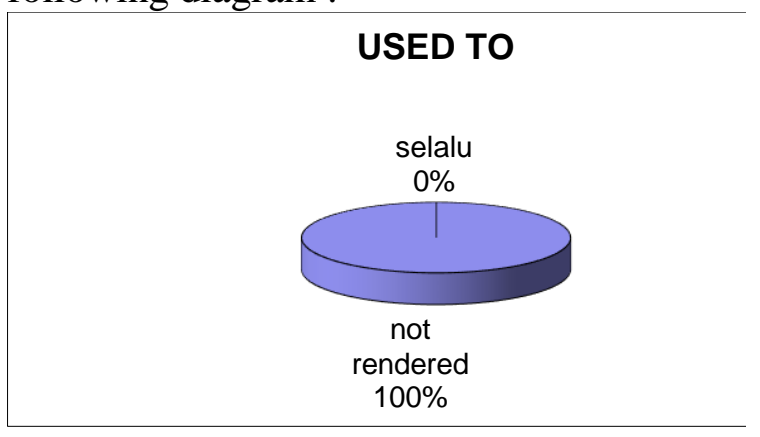

Diagram 10

\section{THE RENDERING OF MODAL}

\section{AUXILIARY}

1. Could

"Could" was rendered into " dapat " ( 9 or $40,90 \%$ ), " татри " ( 7 or $31,81 \%$ ), " bisa " ( 3 or $13,63 \%$ ), " mungkin " ( 1 or $4,54 \%$ ), " not rendered " ( 2 or $9,09 \%$ ) of the total " could " found in the source of data.

2. May
May was rendered into " akan " ( 3 or $33,4 \%)$, " boleh " ( 2 or 22,3 $\%$ ), " bisa " ( 1 or 11,2\%), “ mungkin " ( 1 or $11,2 \%$ ), " not rendered" ( 1 or $11,2 \%$ ) of the total " may " found in the source of data.

3. Will

"Will" was rendered into " akan " ( 74 or $78,72 \%)$, " dapat " ( 2 or $2,13 \%$ ), " bisa " ( 1 or $1,06 \%$ ), and " not rendered" ( 17 or 18,08 $\%$ ) of the total " will " found in the source of data.

4. Can

"Can" was rendered into " dapat " ( 20 or 55,6 \% ), " татри " ( 2 or $5,6 \%$ ), " bisa " ( 9 or $25 \%$ ), " mungkin" (2 or 5,6\% ), " not rendered" ( 9 or $25 \%$ ) of the total " could " found in the source of data.

5. Should

Mostly, should was not rendered ( 6 or $85,71 \%$ ) and " harus " ( 1 or $14,28 \%$ ) of the total " should " found in the source of data.

6. Would

Mostly, would was rendered into "akan " ( 17 or 77,27 \%) and " not rendered " (5 or 77,27 \%) of the total "would " found in the source of data.

7. Shall

Mostly, Shall was rendered into "akan " ( 33 or $89,19 \%$ ) and " not rendered " (4 or 10,81\%) of the total " shall " found in the source of data.

8. Must

Must was not rendered ( 2 or $100 \%$ ) of the total " must " found in the source of data.

9. Might

"Might" was rendered into " akan " ( 1 or $50 \%$ ) and " mungkin " (1 or $50 \%)$ of the total " might " found in the source of data. 


\section{Used to}

Used to was not rendered (1 or $100 \%$ ) of the total " shall " found in the source of data.

The finding of this study shows that context plays a very important role with the meaning of modal auxiliaries. For example : modal auxiliary "could" can be translated into "dapat". Modal auxiliary "will" can be translated into "akan" while "should" and used to sometimes are not translated.

The role of context in determining the meaning of a word within a sentence or a discourse is influence by at least two important factors i.e. situational context, cultural context, and on the natural form of receptor language.

According to Larson ( 1984 : 19 ):

It is not uncommon that passive construction will need to be translated with an active construction or vice versa, depending on the natural form of the receptor language. This indicate that the various form of the equivalence of English modal auxiliaries into Indonesian is reasonable. In addition, Larson (1984:20) state that seldom will a text be translated with the same form as that which occurs in the source language. Certainly, there will be times when by coincidence the match, but a translator should translate the meaning and not concern himself with whether the forms turn out the same or not.

Communication situation also plays a very crucial role in translation. This has been stated by Larson ( 1984:32) The meaning which is chosen will be influenced by the communication situation e.g. by who the speaker is, who the audience is, the traditions of the culture, etc. The speaker or writer, basing his choices on many factors in the communication situation, chooses what he wishes to communicate. Once he has determined the meaning, he is limited to use the forms (grammatical, lexical, phonological) of the language in which he wishes to communicate that meaning. He may choose one form over another in order to give a certain emotive meaning in addition to the information he wishes to convey. He may choose one form over another because he wishes to make some part more prominenr that another, to add some focus to a part of the message.

Newmark (1988:94 - 103) defines that culture as the way of life and its manifestation that are peculiar to community that uses a particular languages its mean of expression. He states that cultural categories which influence a translation consist of ecology, material culture (artifacts), social culture, organizations, customs, activities, procedures, concepts, gestures and habits.

In conclusion, the equivalence of certain words, terms, and grammatical structure from the source language text into the target language text often has different form the target language text.

\section{CONCLUSION}

Based on the analysis of the data, the following conclusions are drawn:

1. The equivalence of the English modal auxiliaries "could" (dapat), "may" (akan), "will" (akan), "can" (dapat), "should" ( harus or not rendered), "would" (akan), "shall" (akan), " must" ( harus or not rendered), "might" (akan), and "used to" ( pernah or not rendered) depending on the context.

2. English modal auxiliaries may represent several alternative meanings. So, the equivalence of modal auxiliaries in Indonesian also varies depending on the context.

3. Modal Auxiliaries may also be not translated depending on the contexts.

Since the limitation of this study is that it does not cover all auxiliaries, it is 
suggested that auxiliaries rather than modal auxiliaries be researched for future studies.

\section{BIBLIOGRAPHY}

Al-Shahab, Omar Sheik H. 1996. Interpretation and the Language of Translation. London: Janus.

Azar, Schampfer Betty. 1992. Fundamental of English Grammar. New Jersey: Prentice Hall Regents.

Baker, Mona. 1992. In other Words: A Coursebook on Translation. London: Routledge. (ed). 1998 [ 2001]. Routledge Encyclopedia of Translation Studies. London: Routledge.

Basnett-McGuire, Susan. 1991. Translation Studies. London and New York: Routledge.

Brown, Gillian and George Yule. 1983. Discourse Analysis. Melbourne: Cambridge University Press.

Burns, Robert B. 1996. Introduction to Research Methods. Melbourne: Longman Australia Pty Ltd.

Catford, J.C. 1979. A linguistic Theory of Translation. London: Oxford University Press.

Chaer, Abdul. 1988. Tata Bahasa Praktis Bahasa Indonesia. Jakarta: Bhratara Karya Aksara.

Echol, John M and Hassan Shadily. 1989. An Indonesian-English Dictionary. Jakarta: PT.Gramedia Pustaka Utama.

Frank, Marcella. 1972. Modern English : A Practical Reference Guide. New Jersey: Prentice Hall, Inc.
Greenbaum, Sidney and Randolph Quirk. 1990. A Student's Grammar of the English language. London and New York: Longman.

Larson, Mildred L. 1984. MeaningBased Translation.London: University press America Inc.

Lubis, Hamid Hasan. 1994, Analisis Wacana Pragmatik. Bandung: Angkasa.

Machali, Rohayah. 2000. Pedoman Bagi Penerjemah. Jakarta: Grasindo

Miles, Matthew B and A. Michael Huberman. Qualitative data Analysis. London: Sage Publication, Inc.

Moeliono, Anton M. 1993. Tata Bahasa Baku Bahasa Indonesia. Jakarta: Depdikbud RI.

Newmark, Peter. 1988. A Textbook of Translation. London: Prentice Hall.

1981. Approaches to Translation. Oxford: Pergamon Press.

1981. About

Translation. Clevedon: Multilingual Matters Ltd.

Nida, EA and Charles Taber. 1974.The Theory and Practice of Translation Leiden:

E.J. Brill.

Oxford Advanced Learner's Dictionary. 1995. Oxford Universityt Press.

Wilkinson, David. 2000. The Researcher's Toolkit. The complete Guide to Practitioner Research. London: Routledge. 